INTERNATIONAL JOURNAL OF MULTIDISCIPLINARY RESEARCH AND ANALYSis

ISSN(print): 2643-9840, ISSN(online): 2643-9875

Volume 04 Issue 06 June 2021

DOI: 10.47191/ijmra/v4-i6-08, Impact Factor: 6.072

Page No.- 732-741

\title{
Exploring Causes and Socio-Economic Impact of Urban Flooding on Kenema City, Eastern Sierra Leone
}

\section{Joseph Christian Adamu Mboma}

Lecturer, Department of Social Studies (Geography \&Environmental Studies Unit) Eastern Polytechnic, Kenema.

\begin{abstract}
Urban flooding has not only become a major threat to Kenema City, Eastern Sierra Leone but to urban communities in the country situated on river confluence or basins. The threats included all but the following; socio-economic and above all environmental impacts. Sierra Leone records flooding every year despite strategies adopted by government and partners in mitigating its consequences on both rural and urban communities. The floods have had negative implications on urban communities' livelihoods, infrastructure, lives and above all socio-economic activities. This paper aims at exploring causes and socio-economic impacts of urban flooding on Kenema City, Eastern Sierra Leone. Comprehensive review of related literature was drawn from individuals, co-authors with in depth experience in research and practice, and web sites for recent studies. A longitudinal research design was used to study flood incidence in the selected communities within five (5) flood disaster years. For sampling technique three (3) communities prone to flooding in the City were randomly selected. Forty-five (45) respondents were selected from the three (3) sampled communities and ten (10) recruited from stakeholders dealing with environmental issues totaling fifty-five (55). There were thirty-five (35) males and twenty (20) females. Two main methods were used; desktop literature and questionnaire. Results show that flooding has been seasonal in the study communities. Various causes of flooding in the City were outlined ranging from deforestation to lack of flood early warning signs. The socio-economic impacts included all but the following; loss of lives and property, loss of livelihood, mass unwanted migration, psychosocial effects, damage to city infrastructure, hindrance to economic growth and development, long recovery from flood events and negative political implications.
\end{abstract}

KEYWORDS: Lambayea stream, Flood, Intensity, Disaster year and Flood prone areas.

\subsection{BACKGROUND}

Flooding is a major hazard affecting the world. According to UNISDR (2015) flooding has destroyed infrastructure and similarly increased human casualties the world over. A typical example was captured during the period 1960-2000 where five (5) million people became homeless globally due to extreme temperature and heavy downpour of rain. Natural hazards have affected mankind for generations making it an old age phenomenon despite limited number of various hazard studies carried out in Africa. According to Kasanga et al, (1996), Maxwell et al, (1999), hazard studies could be classified in a special category known as the physical systems while Songsore and Mc Granahan (1998) categorized it as phenomenon with socio-economic characteristics. Study of hazards especially urban flooding, has to capture key issues such as environmental, socio-economic impacts and more importantly the coping strategies adopted by affected communities. Jongman (2018) postulated that in Europe for the past One Hundred and Fifty (150) years recorded vulnerable urban flood communities has increased by $1000 \%$ while in Sub Saharan Africa catastrophes due to flooding have gone over US\$ 300 Billion in cash. The latter can be attributed to rapid growth of cities (urbanization). Such communities were peopled with low income capability to enable them afford and live in decent communities that were flood free but rather stayed in less expensive structures and poor environmental friendly areas that were imminent for flooding. Urban dwellers in these categories were poor and therefore had no alternative but to dwell in flood prone communities (Owusu Twum K, and Abubakari M, 2019). African countries have disaster management plans to handle flood hazards, but there was still a question of how effective those management plans were developed and implemented in flood prone areas of each country. Related research has clearly shown that flood management plans developed and implemented in piece meal in the affected flood communities were ineffectively managed as opined by Challies et al, (2016). Flooding has caused heinous problems to Kenema City especially in communities situated along the Lambayea Stream. Notable among the destructions caused apart 


\section{Exploring Causes and Socio-Economic Impact of Urban Flooding on Kenema City, Eastern Sierra Leone}

from lives and property on the City includes high incidence of contacting water borne diseases like Cholera and Diarrhea. This is captured in the work of Alderman et al, (2012) and Few (2013) apart from destruction of property and economic losses due to flooding in Accra, Ghana, residents of the flood communities lived in areas at a high risk of contracting diseases such as cholera, malaria and Hepatitis. With all the efforts played by the Kenema City Council, Environmental Protection Agency (EPA) and partners such as moving people from flood prone areas and wetlands in the city, the number of inhabitants increased in these communities. The work of Fatti C. E, and Patel Z, (2013) indicated a number of approaches that are ready to address not only the socio-economic but also environmental and institutional challenges in poor urban communities which ranges from building of trust to community engagement in environmental issues and socio-economic livelihood strategies. But all these have been hampered by urban flood resident's distrust in local authorities and environmental organizations, poor community engagement and above all weak policy implementation by duty bearers (Owusu G, Afutu-Kotey R.L, 2010). In curbing urban flooding in Kenema city, various policies, strategies and laws have been effected but it appears that the more these policies are enforced the more people occupy flood prone areas particularly along the Lambayea Stream. Many people have been stopped from erecting structures in the flood risk zones such as wetlands along streams and water catchment areas to enhance sustainable ecosystem but the efforts of EPA, the Kenema City Council and the Ministry of Lands and Country Planning have been thwarted in this direction. To address this, Herslund L.B, et al, (2016) suggested that to effectively and efficiently adopt urban flooding climate change, related issues and strategies should be encouraged through local participation. This means that local residents of the flood prone areas should be involved in all disaster management programs affecting them and above all incorporate them in the planning, implementation and monitoring and evaluation stages. In February 2021, there was a torrential rainfall and heavy wind which destroyed many structures in Kenema City but what worsened the problem was the flood that occurred in the flood prone communities. Similarly on March 7 2021, there was a heavy downpour of rain in Kenema City causing many residents to vacate their houses, losing property and livestock. This was considered an abnormal as the periods were supposed to be mid-dry season in Sierra Leone but climate change has overturned the normal climatic system. This was captured in the work of Mirhosseini G, et al., (2013) who opines that the impact of climate change on rainfall intensity and frequency has become relevant in recent research. Therefore the intensification of rainfall has direct link with climate change. According to Hettiarachchi S, et al., (2018) intensity of rainfall does not only hinge on climate change but climate change increases the likelihood of extreme rainfall and its intensification creates greater risks of damage in flood events especially in urban regions where the existing infrastructure has not been designed to cope with such risks. With all these concerns, there is a need to address the causes and socio-economic impact of urban flooding on Kenema City, Eastern Sierra Leone.

\subsection{OBJECTIVE}

The objective of this paper is to explore the causes and socio-economic impacts of urban flooding on Kenema City.

\section{1 FLOODING STATUS OF SIERRA LEONE}

After the civil war in 2002, there was only one meteorological station in the country stationed in the capital Freetown. This had negative impact on weather forecast for communities out of the country's capital. In 2017, there were only two operational meteorological stations at Lungi airport and at Wilberforce covering the entire country. This deprived knowledge with adequate weather data and hence disaster such as flooding was prevalent not only in the country's capital but the entire country. As the country remembers the catastrophic flood disaster victims and events in August 2017 particularly in slums, valleys and waterways, one cannot intend for reoccurrence of such in years to come (Kamara, 2017). In the last fifteen years, Sierra Leone has experienced five major floods including the recent 2019 floods in the capital city alone. The Flash flood that occurred in Kenema City in 2014 and 2017 was disastrous as seven houses were demolished and hundreds of people made homeless. They were aided by a Christian organization in areas of food supply though not sufficient (Fabah, 2017). Other organizations made efforts, but the political will and policy to relocate people from the communities remain a major problem. Therefore, the mere reactions of shock and empathy by politicians and policy makers, without embarking on identifying and analyzing the causes of floods and mitigating policies that will, if not totally prevent, but certainly minimize such would cause more problems for the communities. It is prudent for policy makers and disaster response management professionals' to identify strategies or preventive actions that would end up creating disaster risks management through hazard assessments and public sensitization.

\subsection{METHODOLOGY}

This study is a longitudinal research design. It investigates events or phenomena over an extended period. It involves repeated observations of the same variables over the short or long term. The main focus is to make repetitive investigations and make observations. This type of research design targets the same group of people and interviews them at regular intervals. In this way, 


\section{Exploring Causes and Socio-Economic Impact of Urban Flooding on Kenema City, Eastern Sierra Leone}

the behaviors are tracked and variables identified that have caused the change in their behaviors. The main disadvantage of longitudinal research design is that long term research increases the chances of unpredictable outcomes. If the same people cannot be found for study update, then the research ceases. For the fact that qualitative research design involves smaller samples, the result cannot be generalized for a population. Longitudinal research design is flexible and therefore can address research questions of all types (why, how, what). The design helps determine the appropriate data collection methods and selection of respondents.

This study was conducted among major stakeholders dealing with environmental issues as well as those who were affected by regular floods in Kenema City. They included Kenema City Council staff, Environmental Organizations, residents of the selected communities in the City, Environmental Protection Agency (EPA) staff and land owners. Two sampling procedures were used to sample the respondents. The first sampling procedure used was purposive sampling which was used to select communities prone to flooding in Kenema City due to the fact that it had all the variables needed for the completion of the study. Another sampling procedure used was the simple random sampling of flood prone communities and respondents for the study. Simple random sampling was also used to select forty-five (45) respondents from three (3) selected communities and ten (10) respondents were recruited from the stakeholder groups totaling fifty-five (55). There were twenty-five males (25) and thirty (30) females making the total fifty (55) respondents. More females were selected because they were almost always at home. The three (3) communities randomly selected included Nyandeyama, twenty (20) respondents; Kpetewoma, twenty (20); and Lambayama, fifteen (15) respondents totaling forty (45). All these communities are located on the bed of the Lambayea Stream which floods regularly. The selected communities have experienced flooding over decades and therefore were equipped enough to give information. All the selected communities were densely populated and houses clustered together. For data collection, two (2) methods were used. The first was desktop literature for secondary information and the second method questionnaire comprising field work which employed questionnaires and discussions with stakeholders to obtain primary data from respondents.

Data analyzes was done by the use of descriptive statistics. Frequency tables, and percentages were used to present the characteristics of the respondents.

\subsection{RESULT AND DISCUSSION}

\subsection{CAUSES OF FLOODING IN KENEMA CITY}

Table 1: causes of flooding in Kenema City

\begin{tabular}{|c|c|c|c|c|c|}
\hline VARIABLE & $\begin{array}{l}\text { STRONGLY } \\
\text { DISAGREE }\end{array}$ & DISAGREE & NUETRAL & AGREE & $\begin{array}{l}\text { STRONGLY } \\
\text { AGREE }\end{array}$ \\
\hline Torrential rainfall & $\begin{array}{l}2 \\
(4 \%)\end{array}$ & $\begin{array}{l}3 \\
(5 \%)\end{array}$ & $\begin{array}{l}5 \\
(9 \%)\end{array}$ & $\begin{array}{l}25 \\
(45 \%)\end{array}$ & $\begin{array}{l}20 \\
(36 \%)\end{array}$ \\
\hline Incidence of flood & $\begin{array}{l}10 \\
(18 \%)\end{array}$ & $\begin{array}{l}5 \\
(9 \%)\end{array}$ & $\begin{array}{l}8 \\
(15 \%)\end{array}$ & $\begin{array}{l}12 \\
(22 \%)\end{array}$ & $\begin{array}{l}20 \\
(36 \%)\end{array}$ \\
\hline Improper waste disposal & $\begin{array}{l}5 \\
(9 \%)\end{array}$ & $\begin{array}{l}3 \\
(5 \%)\end{array}$ & - & $\begin{array}{l}15 \\
(27 \%)\end{array}$ & $\begin{array}{l}33 \\
(60 \%)\end{array}$ \\
\hline Increase of surface runoff & $\begin{array}{l}2 \\
(4 \%)\end{array}$ & $\begin{array}{l}4 \\
(7 \%)\end{array}$ & $\begin{array}{l}3 \\
(5 \%)\end{array}$ & $\begin{array}{l}18 \\
(33 \%)\end{array}$ & $\begin{array}{l}28 \\
(51 \%)\end{array}$ \\
\hline Poor city planning & $\begin{array}{l}20 \\
(36 \%)\end{array}$ & $\begin{array}{l}15 \\
(27 \%)\end{array}$ & $\begin{array}{l}2 \\
(4 \%)\end{array}$ & $\begin{array}{l}8 \\
(15 \%)\end{array}$ & $\begin{array}{l}10 \\
(18 \%)\end{array}$ \\
\hline $\begin{array}{l}\text { Inadequate drainage } \\
\text { facility }\end{array}$ & $\begin{array}{l}7 \\
(13 \%)\end{array}$ & $\begin{array}{l}5 \\
(9 \%)\end{array}$ & $\begin{array}{l}3 \\
(5 \%)\end{array}$ & $\begin{array}{l}10 \\
(18 \%)\end{array}$ & $\begin{array}{l}30 \\
(55 \%)\end{array}$ \\
\hline $\begin{array}{l}\text { Poor conformity with } \\
\text { environmental laws }\end{array}$ & $\begin{array}{l}5 \\
(9 \%)\end{array}$ & $\begin{array}{l}3 \\
(5 \%)\end{array}$ & $\begin{array}{l}8 \\
(15 \%)\end{array}$ & $\begin{array}{l}15 \\
(27 \%)\end{array}$ & $\begin{array}{l}24 \\
(44 \%)\end{array}$ \\
\hline Land ownership system & $\begin{array}{l}10 \\
(18 \%)\end{array}$ & $\begin{array}{l}10 \\
(18 \%)\end{array}$ & $\begin{array}{l}8 \\
(15 \%)\end{array}$ & $\begin{array}{l}15 \\
(27 \%)\end{array}$ & $\begin{array}{l}12 \\
(22 \%)\end{array}$ \\
\hline Deforestation & - & $\begin{array}{l}2 \\
(4 \%)\end{array}$ & $\begin{array}{l}3 \\
(5 \%)\end{array}$ & $\begin{array}{l}20 \\
(36 \%)\end{array}$ & $\begin{array}{l}30 \\
(55 \%)\end{array}$ \\
\hline $\begin{array}{l}\text { Lack of flood early warning } \\
\text { signs }\end{array}$ & - & - & $\begin{array}{l}5 \\
(9 \%)\end{array}$ & $\begin{array}{l}15 \\
(27 \%)\end{array}$ & $\begin{array}{l}35 \\
(64 \%)\end{array}$ \\
\hline
\end{tabular}

SOURCE: Field Data, 2021. 


\section{Exploring Causes and Socio-Economic Impact of Urban Flooding on Kenema City, Eastern Sierra Leone}

This area identifies and shows major causes of flooding in Kenema City. Data gathered from the study communities indicated that $45 \%$ agreed that flooding is caused by torrential rainfall in the City and $36 \%$ also strongly agreed but indicated that it was seasonal but now it occurs anytime in a year regardless the seasons due to climate change. For the very fact that they agreed that they experienced torrential rainfall which often leads to flooding in their communities it should be noted as fact regardless it sporadic occurrences and it is worth to go by because they were in majority. However, $9 \%$ of the respondents took neutral posture on the grounds that they were aware of torrential rainfall in their communities because they could not distinguish between rainfall patterns. $5 \%$ disagreed while $4 \%$ strongly disagreed. When asked of the incidence of floods in their communities $36 \%$ of the respondents strongly agreed that due to the intensity of rainfall in their communities, the incidence of flood was high. $22 \%$ also said it was high indicting the number of times it occurred within a year particularly in 2017 and 2019 when Kpetewoma and Nyandeyama communities received flash floods five times. However $15 \%$ took neutral position due to the fact that they were business people who spent bulk of their time in the Central Business District (CBD) and are not often around when the flood occurs in their communities. $18 \%$ strongly disagreed and $9 \%$ disagreed on the grounds that their own houses were of a considerable distance from the regular flash flood path. During discussion, $60 \%$ of the respondents strongly agreed that improper waste disposal was a cause of flooding. $27 \%$ agreed but $9 \%$ strongly disagreed while $5 \%$ disagreed on the grounds that they have been doing it over decades due to low waste management in the city without experiencing flash floods of such nature. This suggests that flooding may be more rampant due to improper waste disposal in the study communities. This has implications for the promotion of flood resilience through improved drainage and green infrastructural systems.

When asked whether they have been dumping waste in the main Lambayea Stream in the localities, bulk of the respondents claimed that they were dumping waste in the stream mainly at night and when is raining. The City Council waste management department collects waste across the city commonly known as "Klin Kenema" but only a few have registered with the department because they were paying for the services while majority did not want to pay and therefore preferred dumping their waste in the Lambayea stream. This is in line with Asumadu-Sarkodie S, et al., (2015) who in their studies were interested in the causes and mitigation measures of urban flooding in Accra. One of the major causes they identified was dumping of waste in the main river in Accra which exacerbated sporadic flooding in the City during the raining season. Discussions revealed that the city council through an international organization Welt Hunger Hilfe (WHH) had developed a waste management unit in the council charged with the responsibility of collecting and disposing all wastes in the city but residents and or households should pay a minimal amount of $\$ 1.94$ (Le 20,000) to subsidize for fuel. It was discovered that because they were asked to pay the said amount which the bulk of them could not afford, they preferred dumping wastes in the Lambayea Stream at their own disadvantage. This clearly shows the poverty level of respondents in the selected study communities. Respondents were further asked whether increase of surface run off was another cause of flooding in their communities; twenty-eight of the respondents representing $51 \%$ strongly agreed and eighteen of them representing 33\% agreed forming majority of them accepting the fact that surface run off was another cause of flooding in their communities. This high response came up because the respondents claimed that they were living in lowland communities with numerous hills jutting in. All the run off empty into their communities finding access to the main Lambayea Stream and most of the areas lacked pavements. Therefore the runoff floods the compounds and even destroys gardens with materials such as pebbles, logs, sand, clay and other unwanted materials. This destroys their economic source. This is in line with the work of Braimah M. M, et al., (2014) who opined that in urban areas, roads, pavements, and compacted soil areas have increased impermeable surfaces, thereby increasing surface water runoffs. This has also led to the increase in discharge that overloads drainage channels. However, four of the respondents representing $7 \%$ disagreed and two of them representing $4 \%$ strongly disagreed while three of them representing $5 \%$ were neutral on the issue. This category of respondents took this posture because their houses were not located along the bed of the stream neither in the lowland area but hill slopes with pavements. They had the financial upper hand than the others and therefore were able to construct pavements without the intervention of the city council. Floods rarely affected them inversely. The respondents were asked whether Kenema is poorly planned. $36 \%$ strongly disagreed and $27 \%$ disagreed on the grounds that the outlook of the city is enviable especially in the Central Business District (CBD) which is well planned, paved with enviable infrastructures. However, going towards the outskirt, old CBD areas and along the Lambayea Stream, the city loses its beauty to poor planning. $18 \%$ strongly agreed, $15 \%$ agreed while $4 \%$ took a neutral posture for the fact that they were residing in poorly planned area which floods whenever it rains with great impacts. This clearly shows that the bulk of the study communities particularly Kpetewoma and Nyandeyama areas are situated on wetlands and therefore during the rains, they find it difficult to reside in the communities. It should be noted that most of the buildings erected in these areas were not permitted by the Ministry of Environment and Country Planning and the Environmental Protection Agency (EPA) but the city being traditional setting, local authorities sometimes flout the rules at the detriment of the households that reside in such unregistered structures. Government on the other hand may not want to lose votes and therefore some of the rules are relaxed even where environmentalists advice. Urban growth has encouraged overpopulation and therefore people want to 


\section{Exploring Causes and Socio-Economic Impact of Urban Flooding on Kenema City, Eastern Sierra Leone}

stay and work in cities without considering the consequences on them and their families. As a result, they may reside anywhere in the city such as ghettoes, shanty communities and slums which are evidenced in the study communities. Poor planning of cities may cause numerous problems such as flooding and high diseases. This is captured by Di Baldassarre G, et al., (2010) who stated that poor settlement planning is a major cause of the increasing urban flooding in Africa. This has implications for real estate developers and home owners to understand community and individual impact of flooding considering sustainable urban land use policy and development. Respondents indicated that inadequate drainage facility was another cause of flooding in their communities as $55 \%$ strongly agreed and $18 \%$ agreed that they had problem with adequate drainage facilities in their communities. Seven of the respondents representing $13 \%$ strongly disagreed and five of them representing $9 \%$ disagreed that the cause of flooding in their communities was attributed to inadequate drainage facility while $5 \%$ remained neutral. Their disagreement was based on the fact that they were not residing along the bed of the Lambayea Stream and the lowland areas where runoffs are common often entering buildings, destroying gardens and other property.

Again respondents were asked whether poor conformity with environmental laws was another cause of flooding in their communities. Twenty-four of the respondents representing $44 \%$ strongly agreed, fifteen respondents representing $27 \%$ agreed that poor conformity with environmental laws was a cause of flooding in their communities while eight representing $15 \%$ took a neutral position. Five of the respondents representing $9 \%$ strongly disagreed and three representing $5 \%$ disagreed. A good number of the respondents stated that there were environmental laws but it was not enforced by duty bearers such as the Sanitary Department of Ministry of Health and Sanitation, Environmental Department of the Kenema City Council, and Environmental Protection Agency sub-office in the city. What worsens the situation is the fact that Environmental Health Officers trained to regularly monitor communities within the municipality are ineffective due to low salary, lack of transportation to visit distant sites and above all delay in salary payment. This is in line with Tasantab J.C (2019) who opined that land use control is established as a contributor to flooding. It was found that delays in permit approvals, lack of monitoring and inspection of physical developments, non-conformance with permit laws and regulations, and poor enforcement were responsible for urban floods. According to the data in table one, fifteen of the respondents representing $27 \%$ agreed that land ownership (tenure) system was another cause of flooding in the study communities and twelve of them representing $22 \%$ strongly agreed which forms majority of the respondents who were not happy because of the way landowners were selling protected land areas such as wetlands which contributed immensely to flood their communities. This made some households to be abandoned by their inmates during the rains to take refuge with close family members or friends in other communities within the city that are not flood prone. Ten of the respondents representing $18 \%$ strongly disagreed and further disagreed that land ownership had nothing to do with the flash floods occurrence in the study communities. However, eight of the respondents representing $15 \%$ claimed to be neutral on the issue. During the discussion, it was revealed that the very few who were in agreement were benefitting from the illegal sales and encroachment of the protected and flood prone areas from the local chiefs and landowners and therefore were unable to come up with the correct picture of happenings in the study communities. This was captured in the work of Owusu-Ansah et al. (2018) who mentioned that local chiefs take advantage of government administrative inefficiencies to sell out land designated for urban green, wetlands, riparian lands, and open space. It was observed that wetlands, riparian lands and urban vegetation were being cleared for builtup purposes. A few of the respondents were in disagreement because they had no cordial relationship with the landowners and local chiefs and therefore did not benefit from the illegal sales. The respondents were asked whether deforestation of the Kambui Hills north overlooking the city was a potential cause of flooding in their communities. $64 \%$ strongly agreed, $27 \%$ agreed forming majority of the respondents while $9 \%$ claimed to be neutral on the issue. However, $4 \%$ of the respondents disagreed. Discussions revealed that those who were in agreement were involved in the deforestation activities for their livelihoods such as lumbering, gold mining, farming etc. and they were aware of the fact that the Lambayea Stream had its source in the Kambui Hills. However, $64 \%$ strongly agreed and $27 \%$ agreed that lack of flood early warning signs was a cause of flooding in the study communities' whist $9 \%$ took a neutral position on the issue. Apart from the weather station located on the premise of Eastern Polytechnic campus in Kenema, there was no other weather station in the Region. Discussions revealed that all weather data collected from the station was transmitted to Freetown at the National meteorological department for analysis. All weather and climate information on the City of Kenema was centred on possibility of rainfall and its intensity but there was no standard system that reported on the early warning signs of floods in the City. This had led to many households been trapped in flood prone areas losing lives and property.

\subsection{SOCIO-ECONOMIC IMPACTS OF URBAN FLOODING ON KENEMA CITY.}

The socioeconomic impacts of floods on Kenema City were examined under impacts on household, livelihood assets and infrastructure. Random selection of respondents from various households in flood prone communities in the City was surveyed using questionnaire and discussion guide. Fifty-five (55) respondents were randomly selected from three communities. Flooding 


\section{Exploring Causes and Socio-Economic Impact of Urban Flooding on Kenema City, Eastern Sierra Leone}

of areas used for socio economic activities produces a variety of negative impacts on individuals, their livelihoods and the City infrastructure.

Table 2: Impact of Flooding on Respondents in the study communities in the city.

\begin{tabular}{|l|l|l|l|l|l|}
\hline \multirow{2}{*}{ VARIABLES } & \multicolumn{3}{|c|}{ DISASTER YEAR } \\
\cline { 2 - 6 } & 2010 & 2012 & 2014 & 2017 & 2019 \\
\hline Loss of belongings (property) & $5(9 \%)$ & $10(18 \%)$ & $30(55 \%)$ & $4(7 \%)$ & $6(11 \%)$ \\
\hline Injury of household members & - & $10(18 \%)$ & $45(82 \%)$ & - & - \\
\hline Death of household members & - & $7(13 \%)$ & $45(82 \%)$ & - & $3(5 \%)$ \\
\hline Loss of health & - & $9(16 \%)$ & $42(76 \%)$ & & $4(7 \%)$ \\
\hline Outbreak water borne diseases & $10(18 \%)$ & $8(14 \%)$ & $30(55 \%)$ & $1(2 \%)$ & $6(11 \%)$ \\
\hline Never been affected by flooding & - & - & - & - & - \\
\hline Took less than 1 month to recover & $49(89 \%)$ & - & - & $6(11 \%)$ & - \\
\hline Took 1-6 months to recover & $2(4 \%)$ & $15(27 \%)$ & $20(36 \%)$ & $8(15 \%)$ & $10(18 \%)$ \\
\hline Took 7-12 months to recover & - & $4(7 \%)$ & $51(93 \%)$ & - & \\
\hline Yet to recover & - & $2(4 \%)$ & $53(96 \%)$ & - & - \\
\hline
\end{tabular}

SOURCE: Field Data, 2021.

Out of the fifty-five (55) of the respondents surveyed in the three selected communities in Kenema city (Kpetewoma, Nyandeyama and Lambayama sections), 55\% of them claimed that they suffered severe damage to their property in the 2014 flood disaster. This was the year that the Ebola scourge seriously hit the city particularly the Nyandayama community where many people lost their lives. It was a few minutes of intensive rainfall but disastrous as children, the sick and the aged lost lives. Respondents also indicated that $18 \%$ lost property in 2012, 11\% in 2019, 7\% in 2017 and 5\% in 2010 to flooding. All these years were still remembered by residents of the study communities. $82 \%$ of the respondents also claimed that their family members suffered severe injury in 2014 from the flood, and 22\% in 2012. Flooding also occurred in the study communities in 2010, 2017 and 2019 but no recorded damage was reported on household members of the respondents. When asked about their health status during the disaster years $76 \%$ of the respondents claimed that they had multiple health complications after the floods in $2014,16 \%$ in 2012 and $7 \%$ in 2019. The health complication was high in 2014 due to restrictions made on the movement of people at that time due to Ebola and the flood met all household members at their residence and it occurred at night. Children, the sick and aged suffered from various illnesses and more especially psychological. This was in line with Dziwornu E, Kugbey N (2015) who discovered mental health problems among flood victims and therefore suggested that care must be taken to address the psychological needs of victims in the aftermath of a flood disaster. The loss of loved ones and property can cause depression and stress among adults and children. The psychological impact can last for a long period when their psychological needs are not met quickly. Displacement from one's home, loss of property and livelihood, and disruption of business and social affairs can cause continuing stress. The cost of overcoming these losses can be overwhelming and produce lasting psychological impacts. $55 \%$ of the respondents indicated that they suffered from water borne diseases in 2014 due to the flooding, 18\% in 2010 and 14\% in 2012. It was also claimed by $11 \%$ and $2 \%$ of the respondents that they equally suffered from water borne diseases in 2017 and 2019 respectively. All the respondents claimed that they were affected by regular floods in the city but their recovering periods varied as $89 \%$ indicated that they recovered in less than one month in 2010 and $11 \%$ in 2017. This suggests that the floods they experienced in the two disaster years were not as severe as those experienced in the other three years. However, $36 \%$ of the respondents stated that it took one (1) to six (6) months for them to recover from the flood in 2014, 27\% in 2012 and 2017 respectively. It was also claimed by $18 \%$ of the respondents that they recovered within one (1) and six (6) months from the floods in 2019 and $4 \%$ in $2010.93 \%$ of the respondents claimed that it took six (6) to twelve (12) months to recover from the flood in 2014 and $7 \%$ in 2010 . This was evident in Kpetewoma and Nyandeyama communities where new structures were erected by the respondents on the same land where the structure was destroyed by the flood waters. However, $96 \%$ of them claimed that they had not recovered from the flood of 2014 and 4\% in 2012. Those who claimed not to have recovered from the flood disaster of 2014 were now residing with their neighbours as they were unable to erect their houses or had no livelihood sources left and they were mainly children, the sick and the aged. 


\section{Exploring Causes and Socio-Economic Impact of Urban Flooding on Kenema City, Eastern Sierra Leone}

Table 3: Impacts of Flooding on Respondents' livelihood activities in the study communities.

\begin{tabular}{|l|l|l|l|l|l|}
\hline \multirow{2}{*}{ VARIABLES } & \multicolumn{3}{|c|}{ DISASTER YEAR } \\
\cline { 2 - 6 } & 2010 & 2012 & 2014 & 2017 & 2019 \\
\hline Damage to business & $2(4 \%)$ & $5(9 \%)$ & $45(82 \%)$ & $1(1 \%)$ & $2(4 \%)$ \\
\hline Damage to agricultural activities & $5(9 \%)$ & $4(7 \%)$ & $41(75 \%)$ & $2(4 \%)$ & $3(5 \%)$ \\
\hline Loss of job & - & $12(18 \%)$ & $43(78 \%)$ & - & - \\
\hline Loss of livestock & - & - & $49(89 \%)$ & - & $6(11 \%)$ \\
\hline Destruction of water(sources) wells & $2(4 \%)$ & - & $51(93 \%)$ & - & $3(5 \%)$ \\
\hline Transportation & - & - & $55(100)$ & - & - \\
\hline Never affected by flood & - & - & - & - & - \\
\hline Took less than 1 months to recover & $48(87 \%)$ & - & - & - & $7(13 \%)$ \\
\hline Took 1-6 months to recover & - & $10(18 \%)$ & $15(27 \%)$ & - & $30(55 \%)$ \\
\hline Took 6-12 months to recover & $2(4 \%)$ & - & $47(85 \%)$ & - & $6(11 \%)$ \\
\hline Have not recovered & - & $10(18 \%)$ & $30(55 \%)$ & - & $15(27 \%)$ \\
\hline
\end{tabular}

SOURCE: Field Data, 2021.

Respondents were asked as to whether they had any impact on the businesses due to flooding in the communities, $82 \%$ claimed that they suffered business loss and slow growth in business in 2014, 9\% in 2012 and 4\% in 2010/2019 respectively. However, 1\% of them claimed to have suffered from business loss due to flooding in 2017. The bulk of the respondents residing in the study communities particularly Kpetewoma and Nyandema were business people with large number of dependents and they often brought their business to their houses. They lived in overcrowded homes with poor socio-economic conditions. Some were trading in perishable items which got spoilt in stores due to poor access to roads to move out of their homes to the market. This was in support of Adelekan I, et al (2015) who postulated that human activities increase the risks of flood due to human and ecological interaction and that in Africa, urban floods have become major threats to deal with in the face of poor socio-economic conditions. This was glaring in the selected communities where poor people build houses and live in flood prone areas as those areas were considered affordable. $75 \%$ of the respondents indicated that flooding in their communities had negative impact on their agricultural production and activities in 2014, $9 \%$ in 2010 and $7 \%$ in 2012 . Flooding in the slated years was adverse to the selected communities because agriculture was their main livelihood source. They grew vegetables, maize, rice on the fertile plains. Moreover, $5 \%$ of the respondents claimed that their agricultural activities came to a halt and their crops destroyed in 2019 and $4 \%$ of them stated that agricultural activities were affected in 2017. This made most of them leave the communities for a while but later returned in the dries. Fine grain sediments covered their gardens and agricultural fields. In Lambayama and Kpetewoma communities, solid waste materials deposited by them in the Lambayea stream was deposited in the verandas, gardens and swamps by the flood waters which destroyed their crops for that year. Since agriculture was the main economic activity, crop damage, loss of income, and having work to do during flooding was common phenomena in the study communities. People were forced to change their occupation for their livelihoods. When asked how they coped with their jobs in their communities when flooded which impeded their movement for days, $78 \%$ of the respondents claimed that they lost their jobs in 2014 and $18 \%$ in 2012 but none lost their jobs in 2010, 2017 and 2019. The bulk of the respondents (89\%) experienced loss in livestock management in 2014 and 11\% in 2019. Livestock management was one of the livelihood sources of the respondents especially in pork, poultry, goat and sheep. Most of the structures for the animals were washed away by the floods especially in 2014 while others contracted diseases and died. This had negative implications on the respondents. More so, $93 \%$ of the respondents stated that their wells and taps which were their main sources of getting water were destroyed which limited them from selling fresh and pure water in 2014, 5\% in 2019 and 2\% in 2010. A good number of them sold cold water as one of their major livelihood sources. 100\% of the respondents claimed that they were affected by accessing transportation to and fro to carry their goods and to get to work. The streets were flooded and after the flood water receded, there were a lot of debris making the streets difficult to ply. This affected them in their jobs and above all loss in their businesses. When asked how long it took to recover from the impact of flooding in their communities, $87 \%$ of the respondents stated that it took them less than one month in 2010 and $13 \%$ in 2029 . None of them recovered within the years $(2012,214$ and 2017). However, 55\% of them indicated that it took between one to six months for them to recover in 2019, 27\% in 2014 and $18 \%$ in 2012. This shows that many households suffered various forms of socio-economic hardships such as hunger, limited access to food and good drinking water etc. in the selected study communities. No recovery was reported within the disaster years of 2010 and 2017. This was captured in the work of Adele ken, I.O (2010) who demonstrated that floods damage property, disrupt economic activities, lead to loss of income, emergency cost and changes in morphological 


\section{Exploring Causes and Socio-Economic Impact of Urban Flooding on Kenema City, Eastern Sierra Leone}

process. $85 \%$ of the respondents claimed that it took six to twelve months for them to recover from the hazards of the flood in 2014, $11 \%$ in 2029 and $4 \%$ in 2010. There was high percentage of respondents who suffered from the flood incidence in 2014 because of the spread of Ebola pandemic at the time which restricted the movement of people and socio-economic activities came to a standstill. This had negative impacts on their livelihoods. No respondent claimed recovering in the disaster years of 2012 and 2017. However, $55 \%$ of the respondents claimed that they have not recovered from the 2014 flood hazards, $27 \%$ from the 2019 and 18\% from the 2012 flood hazards. This was evident in the study communities as structures for livestock were destroyed and agricultural low lying areas were reclaimed and dwelling houses constructed. This limited their livelihood sources and many had to change their livelihood strategies which were not as productive as they were before.

Table 4: Impacts of Flooding on the city infrastructure.

\begin{tabular}{|l|l|l|l|l|l|}
\hline \multirow{2}{*}{ VARIABLES } & \multicolumn{3}{|c|}{ DISASTER YEAR } \\
\cline { 2 - 6 } & 2010 & 2012 & 2014 & 2017 & 2019 \\
\hline Damage to structures (houses) & - & $5(9 \%)$ & $49(89 \%)$ & - & $1(2 \%)$ \\
\hline Damage to bridges & - & - & $53(96 \%)$ & - & $2(4 \%)$ \\
\hline Roads damaged and blocked & $2(3 \%)$ & $5(9 \%)$ & $42(76 \%)$ & $3(5 \%)$ & $4(7 \%)$ \\
\hline Electric cables and poles destroyed & - & $6(11 \%)$ & $35(64 \%)$ & $5(9 \%)$ & $9(16 \%)$ \\
\hline Water pipes and taps destroyed & $3(5 \%)$ & $10(18 \%)$ & $30(55 \%)$ & $4(7 \%)$ & $8(15 \%)$ \\
\hline Never been effected by flooding & - & - & - & - & - \\
\hline Took less than 1 month to recover & $35(64 \%)$ & $12(22 \%)$ & $3(5 \%)$ & $2(4 \%)$ & $3(5 \%)$ \\
\hline Took 1-6 months to recover & $5(9 \%)$ & $10(18 \%)$ & $25(45 \%)$ & $8(15 \%)$ & $7(13 \%)$ \\
\hline More than 6 months and above to recover & - & $7(13 \%)$ & $37(67 \%)$ & - & $11(20 \%)-$ \\
\hline Have not recovered & - & - & $53(96 \%)$ & - & $2(4 \%)$ \\
\hline
\end{tabular}

SOURCE: Field Data, 2021.

Respondents were asked as to whether flooding had negative impacts on their infrastructure during the disasters years, $89 \%$ claimed that it destroyed their dwelling houses in 2014, 9\% in 2012 and 2\% in 2019. Destruction of dwelling houses in 2014 was high because the type of houses constructed in flood prone areas were mainly mud and wattle houses and worst still it happened at night. $96 \%$ of the respondents claimed that bridges leading to their communities were destroyed in 2014 and $4 \%$ also indicated destruction of bridges in their communities in 2019 due to flooding. For disaster years of 2010, 2012 and 2017 no damage or destruction of bridges in the study communities were reported. However, $76 \%$ of the respondents claimed that roads leading to their communities and those within were blocked by flowing water and large deposit of debris making movement impossible for road vessels and humans in 2014, 9\% in 2012 and 7\% in 2019. 5\% of the respondents indicated that their roads were blocked by flood waters and debris in 2017 and 3\% in 2010. As economic and social infrastructure such as bridges and roads were damaged, the study communities were cut-off and some economic activities became disrupted. This increased community vulnerability economically, socially and normal life came to a standstill. More over $64 \%$ of the respondents stated that electric cables and poles were destroyed in their communities in 2014, 16\% in 2019, in 2012 while 9\% indicated 2017 as the year when their communities lost electricity supply due to flooding that destroys the facilities. Similar impact of flooding on water wells, taps and pipes was reported as 55\% of the respondents stated that it hits their communities in 2014, 18\% in 2012, 15\% in 2019, 7\% in 2017 and 5\% in 2010. The situation did not only their landscape but also their livelihood source as many depended on water sales. The sources were destroyed and the water was impure for drinking and for other domestic uses. This contamination led to increase prevalence of water borne diseases such as cholera and typhoid. Respondents were asked whether they were affected by flooding during the disaster years, all of them claimed that they were affected though at different levels. In the area of recovering from the flood hazards $64 \%$ of the respondents claimed that they recovered in less than one month in 2010, 22\% in 2012 and $5 \%$ in 2014 and 2019 respectively. However, $4 \%$ claimed that they recovered in less than a month in 2017 . This indicates that the impact of flooding was not seriously destructive and hazardous in 2010 as bulk of the respondents recovered in less than a month. In $2014,45 \%$ of the respondents claimed that they recovered from flood hazards within one and six months, $18 \%$ in $2012,15 \%$ in $2017,13 \%$ in 2019 and $9 \%$ in 2010. Recovery was slow in 2014 as compared to other flood disasters due to the destruction it caused on human, livelihoods and infrastructure. Moreover, $67 \%$ of the respondents stated that they recovered within the period of six and twelve months in 2014, 20\% in 2019 and 13\% in 2012. Recovering from flood's negative impact was more prolonged for some respondents who lost family members and houses particularly in Kpetewoma community were some broken houses were never repaired and hence became a water logged area and a breeding ground for mosquitoes. However, $96 \%$ of the respondents claimed that they 


\section{Exploring Causes and Socio-Economic Impact of Urban Flooding on Kenema City, Eastern Sierra Leone}

never recovered since flooding occurred in their communities in 2014 while $4 \%$ registered similar sentiment for the disaster year of 2019. It was claimed that in the flood disaster years of 2010, 2012 and 2017, respondents had recovered. Information in Tables 2, 3 and 4 show that while some respondents took a short time to recover, some took longer and others never recovered from the previous impact of flooding. The two communities had different recovery patterns after flooding. The fixed community appears to have recuperated faster after the 2014 flooding but the recovery rate seems to be deteriorating.

\subsection{CONCLUSION}

This paper explores causes and impacts of flooding on Kenema City, Eastern Sierra Leone and the objectives included all but the following; examine the causes of flooding and socio-economic impacts of flooding on selected flood prone communities in the city. Longitudinal survey was conducted for five flood disaster years experienced in the selected communities. Data from the study suggests that there were various causes of flooding in the selected communities and some of the causes were attributed to the attitude of the respondents, land owners, City Council and lack of early warning signs of flooding in the city. Other causes were attributed to lack of implementation of environmental policies by duty bearers and poor city planning. The impacts of flooding in the study communities were examined in three ways; on the respondents, their livelihood activities and on city infrastructure. The impact of flooding was badly felt by respondent's themselves and dependents especially in the areas of poor health, loss of life and properties, lack of support and above all difficulty in recovering. For them their livelihood activities were thwarted and some came to a standstill leading them to change to other livelihood activities that was unsustainable while others migrated to other communities. City infrastructures established in the selected communities were destroyed such as water pipes and wells, electric poles and cables, bridges and above all roads were not accessible for days. Therefore there is a need to critically look at various policies, acts, regulations, plans and strategies in mitigating flood occurrence in the city.

\section{REFERENCES}

1) Asumadu-Sarkodie S, Owusu Phebe A, Herath Jayaweera C (2015). Flood risk management in Ghana: A case study in Accra.

2) Adelekan I, Johnson C, Manda M et al (2015). Disaster risk and its reduction: an agenda for urban Africa.

3) Adelekan I.O (2010). Vulnerability of poor urban coastal communities to flooding in Lagos, Nigeria.

4) Braimah M.M, Abdul-Rahaman I, Oppong-Sekyere D et al (2014). A study into the causes of floods and its socio-economic effects on the people of Sawaba in the Bolgatanga Municipality, Upper East, Ghana.

5) Challies E, Newig J, Thaler, T et al (2016). Participatory and Collaborative Governance for Sustainable Flood risk management: an Emerging Research Agenda. Environ Sci Policy.

6) Di Baldassarre G, Montanari A, Lins, H. et al (2010). Flood fatalities in Africa: from diagnosis to mitigation.

7) Dziwornu E, Kugbey N (2015). Mental health problems and coping among flood victims in Ghana: a comparative study of victims and non-victims.

8) Fatti C. E, Patel Z (2013). Perceptions and responses to urban flood risk: implications for climate governance in the South.

9) Few R (2013) Flood hazards, vulnerability and risk reduction. In: Flood hazards and health..

10) Fabah, V.M (2017). Incarnation Congregation of Evangelical Lutheran Church Support to Flood Victims, Sierra Leone.

11) Herslund LB, Jalayer F, Jean-Baptiste $N$ et al (2016). A multi-dimensional assessment of urban vulnerability to climate change in Sub-Saharan Africa.

12) Hettiarachchi S, Wasko C, Sharma A (2018). Increase in flood risk resulting from climate change in a developed urban watershed-the role of storm temporal patterns.

13) Jongman $B$ (2018) Effective adaptation to rising flood risk.

14) Kasanga RK, Cochrane J, Roth M. (1996). Land markets and legal contradictions in the peri-urban area of Accra, Ghana: Informant interviews and secondary data investigations. University Of Wisconsin, Land Tenure Center Research Paper.

15) Kamara, Kortor (2017) Sierra Leone recurrent floods and mudslides. The Patriotic Vanguard News Paper.

16) Mirhosseini G, Srivastava P, Stefanova L (2013). The impact of climate change on rainfall intensity-duration-frequency (IDF) curves in Alabama. Reg Environ Change.

17) Maxwell D, Larbi WO, Lamptey GM, Zukariah S, Klemesu MA. (1999). Farming in the shadow of the city: Changes in land rights and livelihoods in peri-urban Accra. Third World Planning Review.

18) Owusu Twum K, and Abubakari M (2019). Cities and floods: a pragmatic insight into the determinants of households' coping strategies to floods in informal Accra, Ghana. Jàmbá J Disaster Risk Study.

19) Owusu G, Afutu-Kotey R.L, (2010). Poor urban communities and municipal interface in Ghana: A case Study of Accra and Sekondi-Takoradi Metropolis. 


\section{Exploring Causes and Socio-Economic Impact of Urban Flooding on Kenema City, Eastern Sierra Leone}

20) Owusu-Ansah JK, Dery JM, Amoako C (2018). Flood vulnerability and coping mechanisms around the Weija Dam near Accra, Ghana.

21) Songsore J, McGranahan G. (1998). The political economy of household environmental management: Gender, environment and epidemiology in the greater Accra Metropolitan Area. World Development.

22) Tasantab JC (2019). Beyond the plan: how land use control practices influence flood risk in Sekondi-Takoradi. Jàmbá J Disaster Risk Study. 